InOdia $\quad \begin{aligned} & \text { InMedia } \\ & \text { The French Journal of Media Studies }\end{aligned}$

7.1. $\mid 2018$

Visualizing Consumer Culture

\title{
Immigrant consumption and cultural visibility in documentary films by and about Latinos
}

\section{Emilie Cheyroux}

\section{(2) OpenEdition \\ Journals}

\section{Electronic version}

URL: http://journals.openedition.org/inmedia/1192

DOI: 10.4000/inmedia.1192

ISSN: 2259-4728

\section{Publisher}

Center for Research on the English-Speaking World (CREW)

\section{Electronic reference}

Emilie Cheyroux, «Immigrant consumption and cultural visibility in documentary films by and about Latinos », InMedia [Online], 7.1. | 2018, Online since 20 December 2018, connection on 10 December 2020. URL : http://journals.openedition.org/inmedia/1192; DOI : https://doi.org/10.4000/inmedia. 1192

This text was automatically generated on 10 December 2020.

(C) InMedia 


\title{
Immigrant consumption and cultural visibility in documentary films by and about Latinos
}

\author{
Emilie Cheyroux
}

\section{Introduction}

1 As the largest minority group in the United States, with $17.8 \%$ of the population, Latinos represent a potentially lucrative market that advertisers in all kinds of industries have striven to get profit from. ${ }^{1}$ Nevertheless, the studies analyzing the strategies used to attract the Latino consumers have denounced their subsequent commodification into a "generic racialized" homogeneous group. ${ }^{2}$ Scholars have pointed out that the notion of a so-called Latino homogeneity rests on ingrained stereotypes which assume that because they share the same language (except for Brazilians), they must have similar consuming behaviors. ${ }^{3}$ The term "Latino" itself sums up the issue: being an "ethnonym,"-a word that has meaning in the particular social and political context of the United States-or "umbrella word," it erases the myriad nationalities and situations that it covers. ${ }^{4}$ For instance, Cuban Americans do not have the same profile, history or economic power as the recent immigrants who tend to come from the most impoverished parts of Central America. ${ }^{5}$ Neither do firstgeneration Latinos behave, speak or consume the same way as their second-generation children. ${ }^{6}$ Yet, there does not seem to be any satisfying term when dealing with the United States' individuals of Latin American descent. ${ }^{7}$

2 Nevertheless, when Latinos gather under this label, it helps to increase their visibility, especially when they wish to shape a set of cultural politics. As Arlene Dávila explains, since the 1960s, Latinos have been at the forefront of the struggle to counter stereotypes about their own ethnic group. She considers that the marketing strategies they deploy are efforts to enforce their recognition. ${ }^{8}$ Far from being a perfect method, since it runs the risk of reinforcing the idea that Latinos are one homogeneous group, 
identifying as Latino creates a common ground for political action. In the film industry for instance, associations such as the National Association of Latino Independent Producers (NALIP) call attention to the lack of opportunities in the industry and to the constant renewal of stereotypes on screen, such as the "Threat Narrative" portraying Latinos as "aliens" coming to invade the United States. ${ }^{9}$

Along the same lines, in the last four decades, a network of film festivals has developed in the Latino "niche." If this group of festivals has yet to be recognized as a distinctive category, some of these festivals have already built a sound and efficient organization that has turned them into successful events..$^{10}$ Starting in 1976 with the San Antonio Chicano Film Festival, these festivals have multiplied throughout the 1990s as a new form of community gathering and of activism that can be considered to be a renewal of the efforts of the Chicano movement. The goal of these festivals is threefold: to redress the unfairness of representation on screen, behind the camera and in the film industry by showcasing a great variety of movies "by and about" Latinos. ${ }^{11}$

4 These festivals warrant scientific attention since they represent a market generated by people who do not intend to commodify the Latino consumers but offer opportunities to consume, consistent with the efforts to denounce stereotypes. In other words, rather than consuming movies filled with stereotypes-and not just about Latinos-mostly from the mainstream industry, these festivals urge the viewers to invest in a market whose mission is to offer quality content produced by the stereotyped population. Thus, not only do these festivals create a space for "self-representation," 12 they also try to instill new consuming habits in movie-goers. As Dávila explains, "it is in the market and through marketing discourse that [Latinos] are increasingly debating their social identities and public standing." ${ }^{13}$ The movies selected for these events not only function as anti-stereotypical tools supposed to shed light on Latinos' culture, interests, and outlook on their situation within American society, they are also items of consumption likely to transform the film market.

5 Cine Las Americas International Film Festival (Austin, Texas) is part of this category of Latino film festivals. ${ }^{14}$ Since 1998, it has showcased movies from the Americas that would not necessarily reach the US market, and the success has been such that nowadays, about a hundred movies are on the program every year. The festival organizers take pride in the diversity and "artistic excellence" of this program, selecting a wide range of genres and formats from the U.S., Latin America, the Iberian Peninsula, and indigenous productions. ${ }^{15}$ Their marketing strategy aims to stress the fact that the event is open to everyone, not just to Latinos, in order to repudiate the assumption that a Latino film festival is necessarily designed for a Latino audience. From the third year onwards, documentaries have become just as important a part of Cine Las Americas as fiction films, and represent each year about half of the program's content. This choice reveals the rhetorical stakes of the program as, over the years, the documentaries questioning the American policy on immigration as well as the way Latino immigrants are incorporated into the U.S. have been an essential part. This tendency is unsurprising since the Latino population is the fastest growing ethnic group ${ }^{16}$, with a proportion of Latinos reaching $39.1 \%{ }^{17}$ It shows the festival's endeavor to participate in the public debate about immigration.

6 This article studies two short documentaries selected by Cine Las Americas, Shopping to belong (Irene Sosa, 2007) and ¿Tacos o Tacos? (Robert Lemon, 2011), which both explore Latino immigrants' consuming habits. Not only do they confirm that consuming a type 
of product allows individuals to enforce or negotiate aspects of their identity, but they provide material to analyze the social, cultural, political and economic implications of the Latin American immigration to the United States. A professor at Brooklyn College, Irene Sosa is a Venezuelan immigrant,$^{18}$ and Robert Lemon, a scholar who holds a PhD in cultural geography, traces his roots to Mexican grandparents. ${ }^{19}$ Thus, both documentaries share a triple frame of analysis: as they were made by filmmakers who are also scholars of Latino descent, and were released in a Latino film festival, these films belong to the cultural politics concerned with Latinos' lack of recognition in the U.S. Both movies go against the tendency that Dávila identifies as the "[continual] recast" of Latinos "as a foreign rather than an intrinsic component of U.S. society, culture, and history." ${ }^{20}$ In other words, they try to reduce the perceived "otherness" of Latinos. ${ }^{21}$

7 To analyze these documentaries' stakes, this article first briefly explores a few concepts linked to immigrants, more particularly assimilation, identity, as well as integration and hybridization. It then focuses on the content of the documentaries, linking image analysis to the rhetorical purposes of the films in order to examine how Sosa and Lemon make the case that Latinos are an inherent part of the United States.

\section{Conceptual considerations}

\section{Assimilation}

8 Shopping to Belong and ¿Tacos o Tacos? explore the way Latino immigrants use their economic power in the United States. Both work on the assumption that the status of immigrant leads to specific patterns of consuming behavior. While Irene Sosa decided to focus on shopping habits - mainly for clothes - in the New York City vicinity, Robert Lemon concentrated on the consumption of tacos in Austin, Texas. To shed light on Mexican immigrants' habits in the city, he based his movie on a comparative study with Anglos' eating routine, which is different both in content and geographical location. ${ }^{22}$

While both documentaries revolve around the symbolic value of consumption, their conclusions about immigrant assimilation are opposite: Shopping To Belong shows Latinos who strive to reproduce the American frantic routine of consumption in order to adopt the welcoming countries' habits whereas ¿Tacos o Tacos? portrays Mexican immigrants who look for traditional food made by a Mexican cook that reminds them of their homeland. Though opposite, these behaviors are in tune with the current research about assimilation, which no longer construes of the phenomenon as a straight process and takes into account the fact that it might be hindered by a variety of social, economic, familial and even gender factors. ${ }^{23}$ Additionally, as Marilyn Halter explains, current immigrants tend to embrace "self-conscious consumption" in order to reinforce the identity they choose for themselves. ${ }^{24}$

10 To expand on these ideas, the concept of "imagined community" coined by Benedict Anderson is particularly useful. Anderson stated that members of a nation had the capacity to delineate their sense of belonging to a community thanks to their "imagination" since they would never be able to get to know all their fellow-members. ${ }^{25}$ Arjun Appadurai used the concept to study immigrants in the context of globalization, explaining that the use of their "imagination" helped them to reinforce their sense of belonging to the community they had left, a process that thus occurred beyond 
borders. ${ }^{26}$ Tacos o Tacos? illustrates Appadurai's thesis as the film shows immigrants gathering around a Mexican food truck in order to bolster their Mexican identity. In other words, their sense of belonging to the Mexican community has led them to develop a special pattern of consumption in Austin.

However, the Mexican immigrants showed in the film also strive to adopt Americans' strong work ethics and the taco truck owner articulates a speech about offer and demand, in keeping with the logic of capitalism. Similarly, in Shopping to Belong, immigrants insist on their efforts to behave like Americans, which does not mean that they do not still identify as Guatemalans or Dominicans for example. Thus, both documentaries demonstrate that Latino immigrants have the flexibility to "imagine" that they belong to and in American society even if they can still identify as members of a foreign community. The question the films implicitly ask, which resonates with Leo R. Chavez's research about "incorporation" of immigrants, is whether the process of assimilation can go both ways and whether the U.S. can "imagine [immigrants] as members of the community", since they undoubtedly "increasingly acquir[e] experiences, knowledge, and modes of behavior that tie them to US society." ${ }^{27} \mathrm{He}$ insists on using the term "incorporation" since it implies acceptance from the welcoming country, a "new angle" of assimilation that was explored by Tomas Jimenez after moving back to the Silicon Valley and noticing the influences immigrants and the "super-diverse" communities had even on "the most established people in the United States." ${ }^{28}$ Jimenez however also identified "a paralyzed white identity," afraid of losing its dominant position, an issue both documentaries hint at. This issue is tied to the concept of identity and to individuals' perception of themselves in a society. The negotiable quality of identity inevitably calls for a discussion about its formation.

\section{Identity negotiation}

The debate to determine whether identity is an essentialist or a constructivist notion has highlighted its complex and even thorny nature. That identity is a blend of both inherited and acquired features seems to be a sound basis to understand an individual but fails to convey its complexity. ${ }^{29}$ Identity Negotiation Theory (INT) defines identity as composite and multifaceted involving, according to Stella Ting-Toomey, "cultural, ethnic, religious, social class, gender, sexual orientation, professional, family/relational role, and personal image(s)." ${ }^{30}$ As she explains, the term "negotiation" refers to "the exchange of verbal and non-verbal messages between the two or more communicators in maintaining, threatening, or uplifting the various socio-cultural group-based or unique personal-based identity images of the other in situ." Thus, the negotiation process involves intergroup communication, a process that can turn out to be difficult for immigrants. The tensions they can face in negotiating their identity rests on both their desire to be accepted and on their need not to forget their roots.

Additionally, if we posit that identity is a personal construction rooted in individuals' perception of themselves and the way they negotiate aspects of their identity, then Stayman and Rohit's model of situational ethnicity-whose core concept is that of "felt ethnicity"-provides a meaningful matrix of analysis. ${ }^{31}$ Their study analyzes the different variables that intensify "felt ethnicity," such as the "social situation" and the "product type," and how they shape consuming behavior. The preliminary assumption of their model is that any individual has a "self-designated identity" (belonging to a 
group) and that "felt identity" is different because it is a function of identification intensity. According to the "antecedent state" in which the person is or the "social situations," this identity can be felt more intensely, which in turns leads to a particular type of consuming behavior. For instance, studying Chinese, Mexican and Anglo individuals, they came to conclusions about their perception of appropriate food for a given social situation. One of them was that Mexicans would rather eat Mexican food with family than with business partners.

This model seems particularly relevant for both documentaries since, according to what the interviewees feel in the particular city in which they live, and according to the social situation they are in, they choose their consuming patterns. In addition, Johanna Zmud and Carlos Arce argue that "social surroundings" and "cultural identity" are essential preliminary variables that influence consumers, two of which are crucial for the study of Latinos in a particular city. ${ }^{32}$ In Shopping to Belong, Sosa insists on the cultural citizenship her interviewees try to acquire. Even in the multicultural city that is New York City, she shows that Latinos are deeply influenced by a sense of inferiority that urges them to buy any item (clothes, cars) that can contribute to their blending in. Conversely, ¿Tacos o Tacos? portrays Mexican families who intend to maintain their inherited cultural identity. It is a feeling of nostalgia that makes them consume " chilanga" food-cooked the same way as in Mexico City-in a particular neighborhood of Austin. These different behavioral patterns confirm that identity formation is a complex process that can depend on people's identification(s), and on their social and urban surroundings.

\section{Integration and hybridization}

15 The diverging behaviors portrayed in these two documentaries usher in a debate about two notions that Dear and Burridge consider "slippery," yet that are at the core of the rhetorical purpose of both documentaries: integration and hybridization. ${ }^{33}$ According to them, integration happens when two elements become dependent without an alteration of the antecedents whereas hybridization is the creation of "novel forms and practices (...) and requires that engaged agents be geographically adjacent for their production to occur." ${ }^{34}$ While Sosa shows Latinos who strive to adopt American ways to be integrated into American society, Lemon deals with the food hybridization that has resulted from the encounter between Mexican and Anglo cultures. The outcomes of the films are similar. In Shopping to Belong, the observation of the Latino immigrants concludes on their inadequacy, and in spite of the success of hybrid food in Austin, ¿Tacos o Tacos? shows that the two communities continue to evolve separately. Both films shed light on the boundary that Latinos cannot seem to cross even if they contribute to the economic well being of the United States. While Dear and Burridge acknowledge the fact that integration and hybridization can sometimes "mutually reinforce" themselves and "develop concurrently," both documentaries conclude that it is not the case. For instance, ¿Tacos o Tacos? implicitly shows that the hybridization of American food practices (Tex-Mex) has not led to more spatial integration of Latinos in Austin. Though commenting on group separation in Austin is not the main purpose of the documentary, a few comments about intergroup tensions keep referring to the issue of the difficult incorporation of Latino immigrants in US society. 


\section{Consumption and the visualization of cultural identity}

Both documentaries confirm the idea that one's sense of identity leads to a corresponding type of consuming behavior that is deeply influenced by one's geographical origin, social position, or family background. To illustrate this idea, which resonates with Bourdieu's concept of "habitus," Irene Sosa and Robert Lemon both show the consumers while they are shopping or eating. ${ }^{35}$ They also capture their testimonies, a technique often used in documentaries as it puts the viewers in direct contact with the interviewee's words. ${ }^{36}$

In Shopping To Belong, the Latinos interviewed explain that they shop frantically in order to feel that they belong in American society. The very first interviewee sets the tone: since shopping is part of American culture, it is paramount for him not call that habit into question. For another interviewee, becoming an American citizen is a threefold process: "getting used to life in this country, which means work, leisure, and shopping. ${ }^{37}$ When these two interviewees explain that they do not question one of the United States' core values, not only do they express their desire to belong, but they counter the stereotypical idea that immigrants threaten American culture.

Additionally, in order to show that Latinos have learned the skills of shopping, Irene Sosa multiplies the shots of crowds in malls and on Latinos buying items. They are thus portrayed like any other American consumer, spending some of their free time shopping. As the camera follows them scrutinizing clothing items, it suggests that they have managed to master the "art" of shopping. The first female interviewee shows that she has a very good grasp of her shopping options, as she is capable of listing numerous stores. She even expresses her fascination for Marshalls: "Marshalls fascinates me because Marshalls sells you quality merchandise at a low price." ${ }^{38}$ In this particular testimony, the movie shows that she has fully comprehended the process of shopping for bargains (Figure 1). Thus, Sosa implies that Latinos have managed to internalize one of the most important tenets of American society: consumerism. 


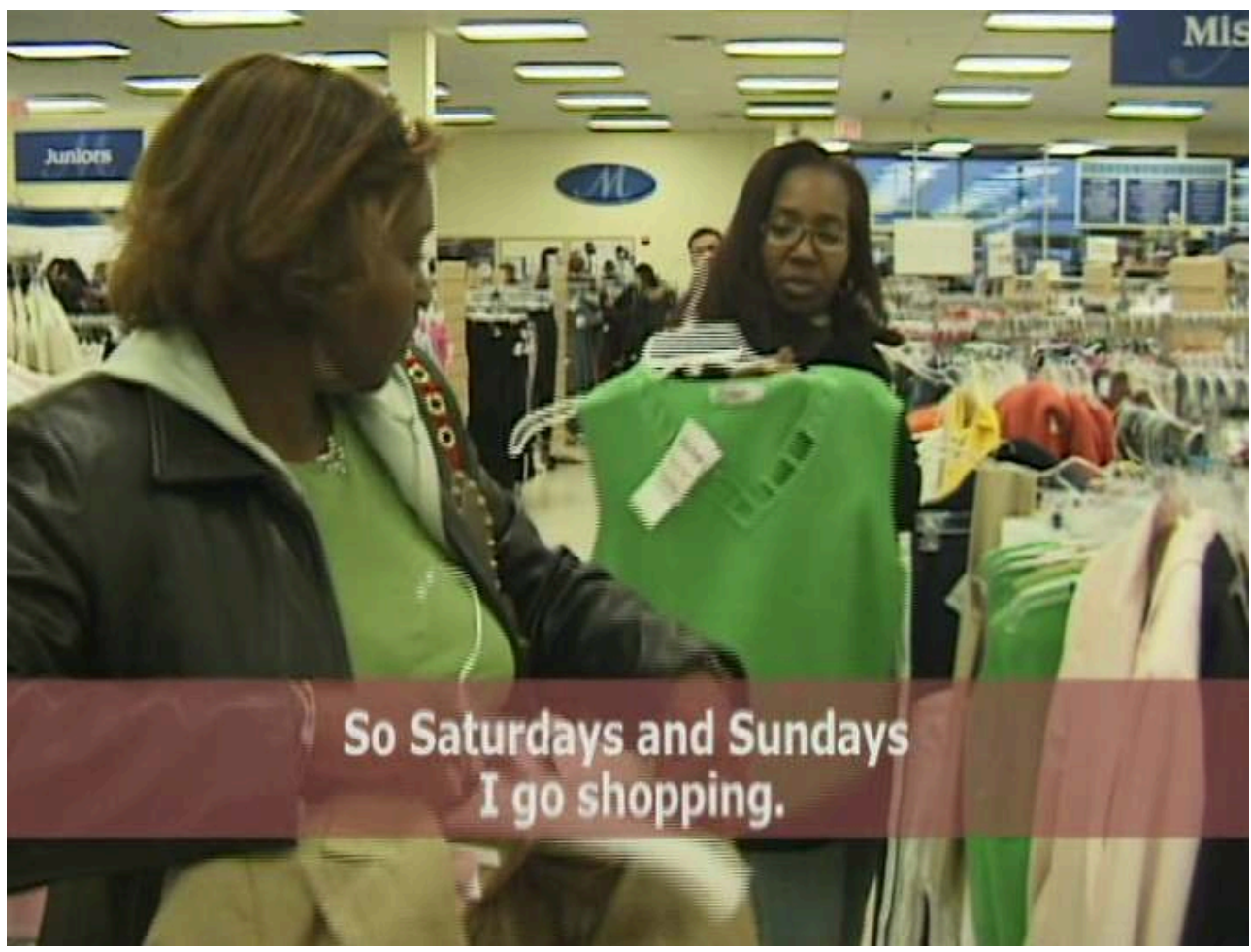

Figure 1. Latinas shopping and looking for bargains

In ¿Tacos o Tacos?, the cultural identity Latinos strive to reinforce is not American but Mexican. As a cultural geographer himself, Lemon builds on Barthes' idea that food has implications that go beyond eating. Being "a system of communication, a body of images, a protocol of usages, situations, and behavior," food acts as a fashion statement. ${ }^{39}$ The documentary shows that the Mexican immigrants of the city of Austin reinforce their cultural identity eating traditional Mexican tacos, cooked in a truck owned by a Mexican chef and set in East Austin. The Anglo inhabitants and tourists, on the contrary, prefer to eat tacos from the South Congress food trucks. In the documentary, Lemon explores each taco truck with the same scrutiny, interviewing the customers and the owners. He inserts several shots that enable the viewer to quickly identify the differences between the two types of tacos, taco trucks and locations and most importantly, the difference between the reasons why people choose a particular type of food.

The Anglo consumers explain that they come to South Congress to find "fun" Tex-Mex food. The Mighty Cone truck they order from is a perfect illustration of the originality they are looking for as the food is served in a tortilla rolled in a cone. The close-ups show a cone generously filled with a hotchpotch of ingredients (Figure 2). On the contrary, the Mexican truck El Guero offers either tortas (a sort of sandwich) or traditional tacos with meat, onions, cilantro and a little cheese. Since the owner is more likely to cater to Mexico City immigrants, he respects the recipes fashionable in that city (Figure 2). 

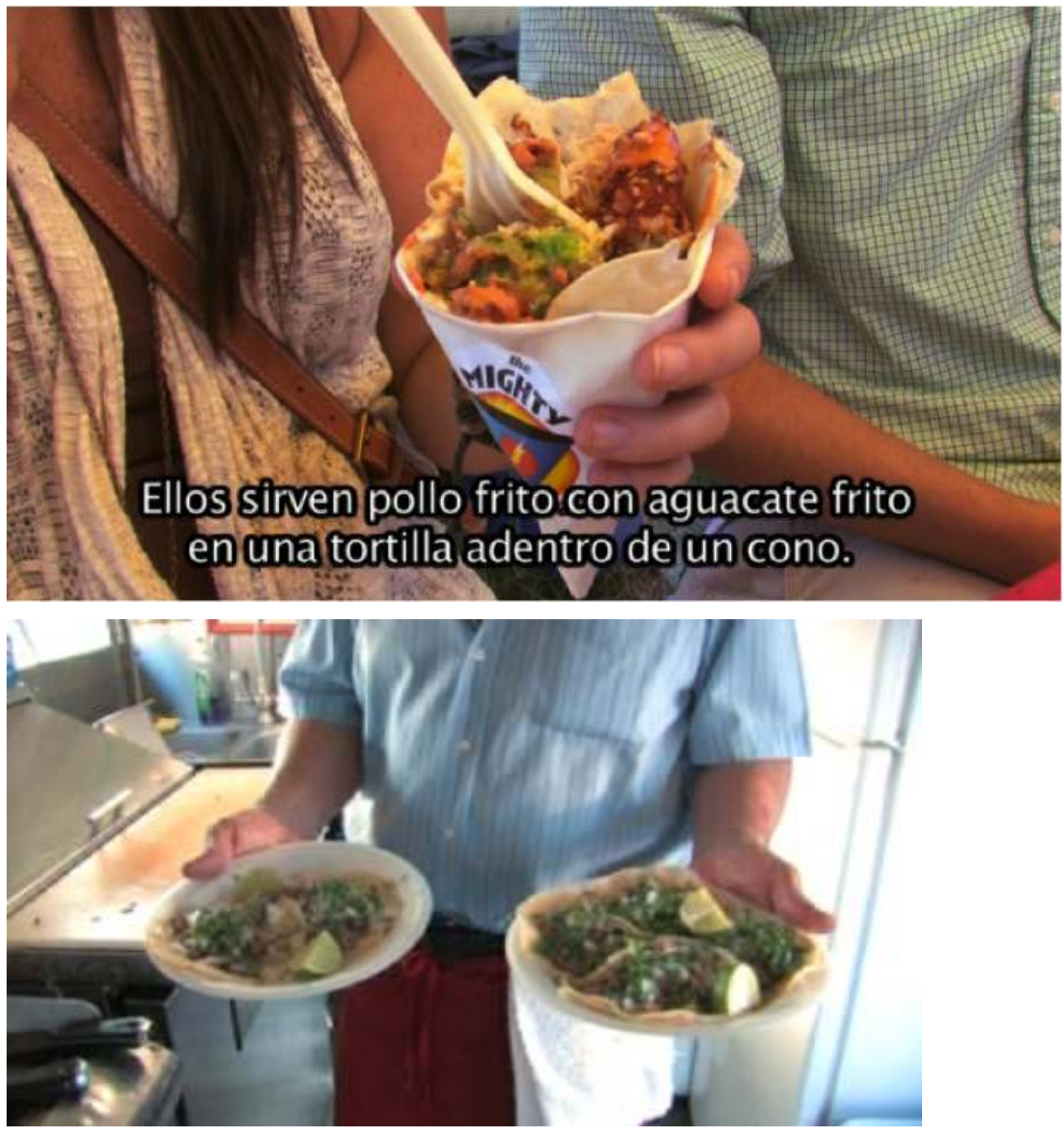

Figure 2: The Mighty Cone versus the traditional Mexican taco

21 In terms of social surroundings, the taco trucks are situated on two completely different parts of town. The Mighty Cone is in the neighborhood of South Congress, often dubbed "SoCo." As one interviewee explains, it is "relaxed, laid-back, funky, fresh, and young," thus in tune with the official motto of the city "Keep Austin Weird." This "weirdness" is in keeping with the people who frequently visit that part of town. One close-up shows that a customer owns a teacup pig as a pet while another one comments on the particularity of the people who often visit the place: "There's a saying that goes 'we're all here because we're not all there' (Figure 3)." Lemon also interviews a couple who has come from Houston to experience Austin's taco trucks since, as they explain, they would never trust the hygiene of their city's vendors. These customers epitomize "culinary tourism," whose purpose is to travel in order to taste the food of a particular place. ${ }^{40}$ That they chose South Congress proves that it has gained recognition for its originality. The owner, a divorced mother who has been working in the restaurant business for years, confirms that she has adapted to the demands of her clientele and even shows that she offers organic peanut-butter bone-shaped cookies for dogs to match with the expectations of her patrons. 

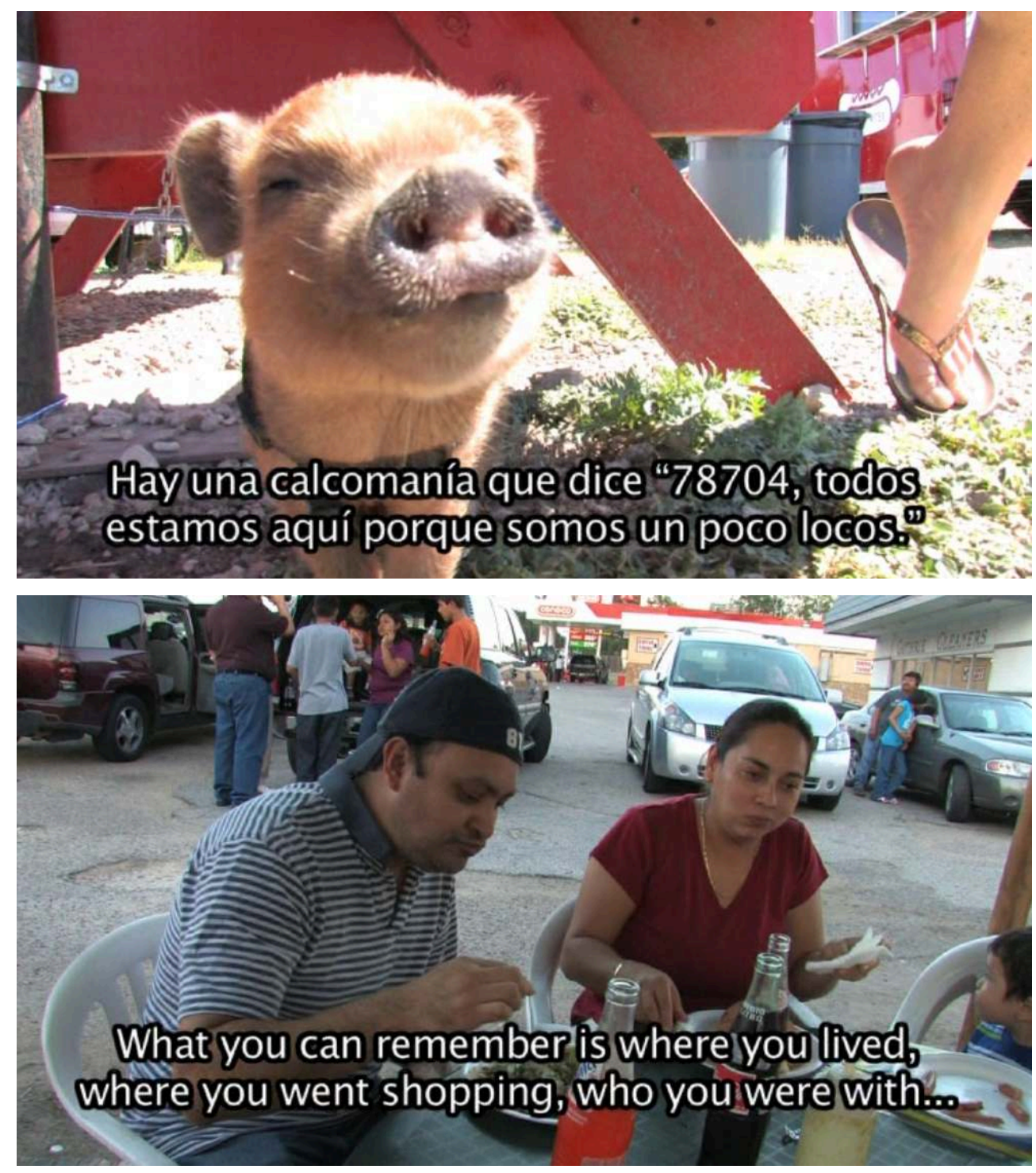

Figure 3: Weird versus traditional

The ambiance in East Austin, where the Mexican food truck El Guero is parked, is much different. The location is less fancy. It is in a parking lot by a busy road, and the tables and chairs used by the customers are yard furniture (Figure 4). The interviewees testify that eating from the taco truck reminds them of their life in Mexico, where eating is a community activity that allows them to get together with their friends and especially with their family (Figure 3). One woman insists on the fact that consuming these tacos allows her to keep in touch with her cultural roots. It resonates with Roland Barthes' comments about food bringing "the memory of the soil." ${ }^{41}$ For the Mexican immigrants, the tacos are used as tangible items that directly bring about the smells, textures and experiences of the homeland into their everyday lives. ¿Tacos o Tacos? thus draws a clear line between two modes of consumption, one based on "bourgeois" or "hip" consumerism offered by an owner who caters to middle-class patrons and another based on the behaviors of working-class immigrant populations who usually associate food with nostalgia for their homelands. ${ }^{42}$

To highlight the differences in taste, the opening sequence's interview inquires about the use of cheese. Lemon asks the Mexican interviewees why they dislike Tex-Mex 
cuisine and one answers that cheese should not be used that much. Then, a cut shows an Anglo woman in South Congress who replies that in Tex-Mex cuisine, she prefers "queso," the dish made with melted Velveeta cheese. In spite of showing that Tex-Mex and Mexican tastes are not interchangeable, this sequence also suggests that both cuisines are nevertheless linked. When the Mexican interviewee implies that Anglos should not use too much cheese, his frame of reference is the traditional recipe from his country. Apart from the slight judgment that he seems to pass, this sequence sheds light on the hybridization that has led to Tex-Mex food. The traditional recipe of tacos was adapted to American tastes and thus, includes a greater amount of cheese. Additionally, in South Congress, with the creativity generated by that particular place, further hybridization has led to the creation of a "SoCo-Mex" cuisine. It may not be an official label-since it is used by an interviewee from the documentary-the expression nonetheless underlines the fertility of the food landscape in Austin.
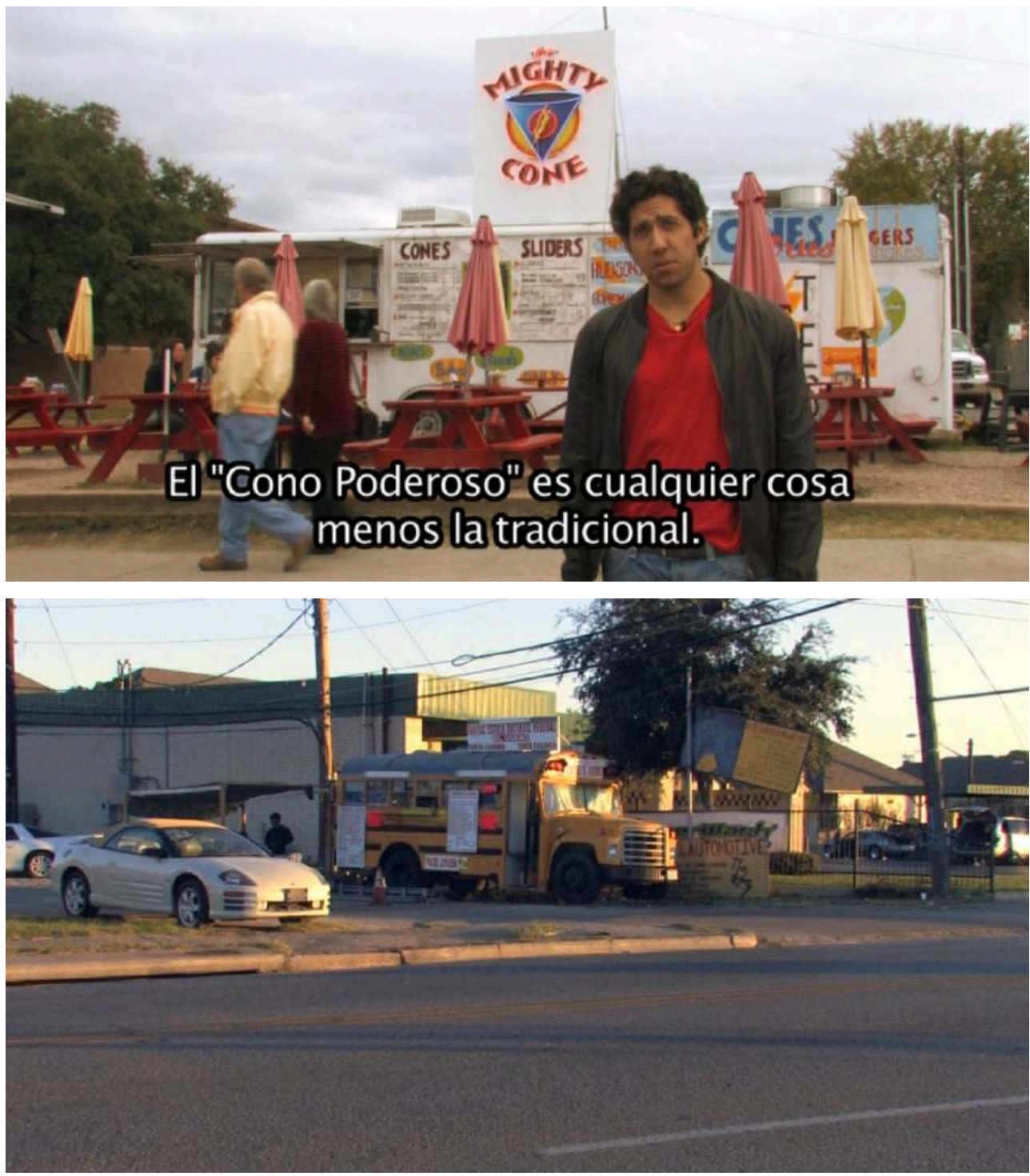

Figure 4: Truck locations: SoCo versus an East Austin parking lot

However, in spite of the success of hybrid food in Austin, the documentary highlights the clear spatial separation between the Mexican and Anglo communities, a reality made obvious by the numerous split screens that Lemon uses. In addition, the 
alternation of shots between the two neighborhoods where the trucks are located underlines the absence of contact between its patrons. As the owner of El Guero explains, he was once almost expelled from the parking lot because the owner of the adjacent carwash - that we guess is Anglo - thought that his truck was a nuisance. He immediately adds "because he doesn't like us, our raza." He thus identifies a xenophobic behavior criticizing the excessive visibility of the Mexican population. Interestingly, the name of his truck means "the blond guy," probably a humorous comment about his situation in the United States and a sarcastic remark indicating that he also has a stereotypical conception of the American man. His remark could seem like a mundane comment yet a similar one is heard in Shopping to Belong by a female interviewee who had the impression that she was being stared at in a park because of the color of her skin. Thus, more than representing consuming behaviors, these two documentaries delve into the issue of the perceived lack of acceptance Latino immigrants feel in American society in spite of their efforts and on the excessive visibility they can be blamed for.

Though it was released a few years before Donald Trump's presidency, ¿Tacos o Tacos? illustrates a debate that came forth during his campaign. In late 2016, Marco Gutierrez, founder of the group Latinos for Trump, warned that if the Republican Party's candidate lost, there would be a "taco truck on every corner," claiming that his culture was "imposing" and "causing problems." ${ }^{43}$ This comment on Latino immigrants' excessive visibility resonates with the comment the owner of "El Guero" had to face but also with the "Threat Narrative" that considers them to be an invasion and a danger to the Anglo culture's purity claimed by Trump supporters. Some social media users humorously replied that "a taco truck on every corner" would be their dream, illustrating the intensity with which numerous people, and especially Texans, enjoy tacos. One could even argue that they seem proud of living in a nation made up of immigrants who contribute to the cultural diversity of the country. Yet, the films ask if Latinos will ever reach a state of inclusive visibility that accepts the hybrid culture resulting from their presence. They both draw a pessimistic assessment of the situation, suggesting that Latinos either have to perform or hide in order to avoid being too visible.

\section{(In)visibility of Latinos}

\section{The Performance of Invisibility in Shopping to Belong}

Stayman and Rohit have showed that felt identity depends on how someone feels in a particular place or situation. Nevertheless, in both documentaries, it seems that an unconscious understanding of historical dynamics might also influence the intensity of identity, especially the socio-economic and even racial issues that have affected Latinos in the U.S. for many decades.

In Shopping to Belong, Irene Sosa shows that her interviewees do not feel like they belong in American society because the acceptance of their efforts has not been validated. They strive to blend in, conveying the idea that they perform when they go shopping, and put on clothes as if it were a costume that helped them do so. The young Latina's story about her uneasy experience in the park where the insisting stares she received urged her to go shopping and find suitable clothes shows that this issue goes beyond the mere choice of outfits. The mimicking of behavior obscures a desperate 
need not to be discriminated against. Her testimony is reinforced by another story told by a young man who was assumed to be a thief in a store when the alarm went off "because of [his] race or [his] looks." It is thus made clear in the documentary that Latinos feel that they have a hard time blending in because of their "brown" complexion and that they are not accepted as part of the "imagined community" of Americans.

One shopping scene is particularly eloquent to illustrate the Latinos' wishes to be invisible and even white. Sosa follows two Dominican Latinas in a store and shows them grabbing white Venetian masks to play with them (Figure 5). The insertion of this scene reveals Sosa's wish to deal with racial biases towards Latinos. She explains that she chose to use this particular scene, which she insists was not staged by her, to illustrate the wish people have to "be somebody else" and for Dominicans the wish to be white. ${ }^{44}$ As a filmmaker, one can only assume that she was also hinting at what Daniel Bernardi calls the "persistence of whiteness" 45 in Hollywood movies and that she might have been aware of the leading roles she had given to Latinos in her documentary.

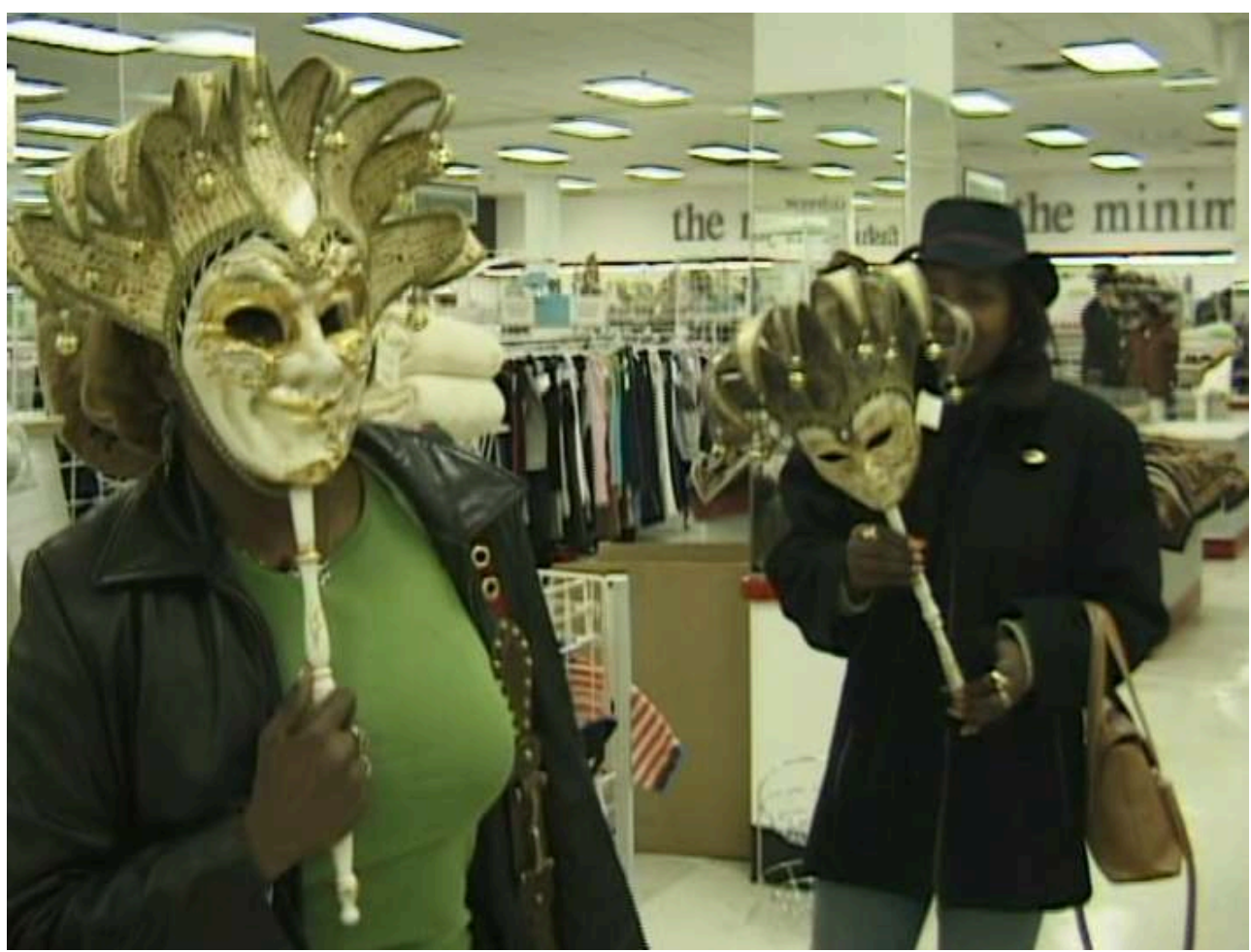

Figure 5: Putting on white masks

Sosa also points to the issues surrounding the mastery of the English language for foreigners. One interviewee explains that he has a heavy accent and that, in order to be left alone, his most successful strategy has been to show off his economic power, with an expensive car or a luxury watch. According to him, money is a "defense mechanism" that gives him the respect he claims he would not get otherwise. He explains that his life is easier with his possessions since no one tries, as he explains, to "mess with him" because he is Latino. What is implied is that he has already had to face such an uncomfortable situation. The tone of his voice shows resentment towards the "hypocritical" acceptance that he gets by conspicuously displaying his wealth. Thus, Sosa draws on the compassion and emotional involvement of the viewer to highlight a sense of injustice. Despite his accent, his mastery of English must have been sufficient 
to bring him success and he is showed as someone who has succeeded in the art business. His testimony sheds light on the "normative ideals of culture, language, gender, and race" within American society that prevent Latinos' inclusion. ${ }^{46}$ Not only does Sosa strives to point the absurdity of these norms but she also shows that Latinos' lack of compatibility with these norms have not prevented them from internalizing the most important of American values.

The contribution of Latinos as workers is a constant reminder in the movie. Even the stealthiest of shot shows Latinos working. Most of them occupy working-class jobs and are construction workers or cleaners. Sosa thus portrays the reality of job stratification to the United States and the fact that Latinos have traditionally filled these positions when arriving to the U.S. ${ }^{47}$ With the very first sequence of the movie, Sosa seems to insist on the fact that her interviewees went through an airport and thus, did not illegally cross the border, as the stereotypical idea of Latinos' arrival would imply. She shows a movement on a map from Latin America to the United States merged with the landing of a plane. Set in the beginning, it is a clear indicator that she wants the viewer to believe that the Latinos she interviews are contributing to the economic well being of the country. And throughout the movie, the numerous shots on the escalators indicate that Latinos are part of all strata of the economic ladder and that they can either go up or down, like any other American. When they are not working, Sosa shows them shopping. As she lingers on a revolving door, she implies that Latinos are caught in the customary yet dizzying process of making money and instantly spending it, but also that their performance is going nowhere towards the process of acceptance, one that should be gradual and linear. She seems to be saying that if the Latinos have internalized American cultural habits, then the U.S. should accept them, a conclusion the movie never reaches.

Not only does Sosa show that Latinos are hardworking, but she highlights the nobility of the reasons why they are in the U.S., having them testify about their families. She uses a certain form of pathos to draw the viewers' sympathy. Most of her interviewees are separated from their families but devoted to them in spite of the distance (Figure 6). A few of the interviewees insist on the fact that they shop to fill the void created by the absence of their family members. Most of the items they purchase are sent out of the country every week. According to one of them, it is their reason for living and a way to somehow "transport" themselves back home. Shopping therefore allows Latino immigrants to belong in their homeland as well, as if they had one foot in each country, as one of them describes. Thus, Sosa portrays Latinos as hard-working selfless people whose behaviors are very similar to the American traditional stories of parental sacrifice. 


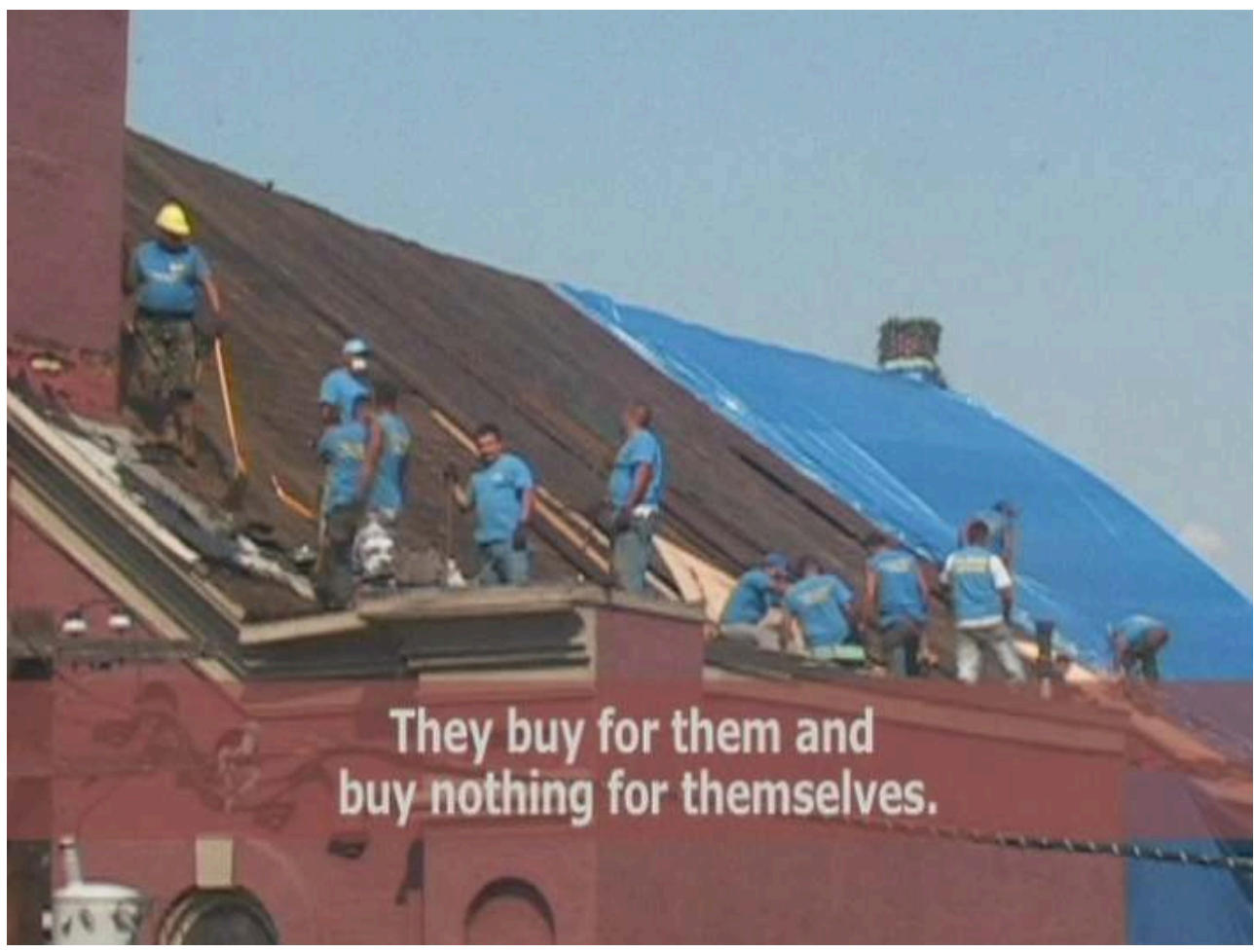

Figure 6. Latino construction workers

At some point in the movie, Sosa chooses to insert a General Motors commercial in which a Spanish voice-over explains that no one should be denied a shot at the American Dream. The voice-over implies that America will keep movie forward (adelante) as long as consumers show support to the brand. In a point-of-view shot showing a never-ending road, the voice insists that the American Dream also belongs to Latinos and therefore, the brand offers the possibility to pay for the car by installments. The addition of this commercial raises questions about the rest of the documentary. Indeed, Sosa seems to point to the hypocrisy of wooing of Latinos. If the commercial accepts to speak in Spanish, to offer them opportunities to fulfill the American Dream like any other American citizen then, why are issues of race, language and culture still obstacles? She seems to come to the same conclusions as Davila: "Even as legal citizens, members of these groups have not reaped the benefits supposedly afforded by 'citizenship,' while their cultural, racial, and linguistic difference renders them forever suspects and potential threats." ${ }^{48}$ Marketers have created a commercial to use Latinos' desire to belong and increase their sales but that reinforces their separation from the mainstream. What stands out in the movie is that Latinos have to put on a show to belong yet, they are still considered to be a separate group. In keeping with Dávila's ideas, the film seems to ask if the U.S. will ever be a united nation proud of the diversity of its population. ${ }^{49}$

In spite of setting the movie in New York City, Irene Sosa did not choose to exploit the image of the Statue of Liberty welcoming immigrants. In ¿Tacos o Tacos? on the contrary, the history of Austin is crucial to understand the movie. Robert Lemon does not only teach us about food ways, his pedagogical stance is combined with a sociological analysis of the cultural, economic and spatial divisions in the Texan capital city. While in her analysis of the fiction film Tortilla Soup (Maria Ripoll, Samuel Golwyn Films, 2001) Laura Lindenfel argues that the visualization of ethnic food in Hollywood 
movies often "erase[s] the labor, history, and experience of Mexican people in the US," with his documentary, Lemon uses food to showcase these elements. ${ }^{50}$

\section{Food for thought on the spatial invisibility of Latinos in ¿Tacos 0 Tacos?}

In ¿Tacos o Tacos?, the separation that is made visible between the Mexican and Anglo consumers is directly linked to the past of the city since Austin used to be a segregated town. In 1928, after the enactment of a city plan, it was decided that East Austin, in other words the neighborhood east of what is today the I-35 highway, was going to be the "Negro District." ${ }^{51}$ Mexicans underwent the same treatment as African Americans since white showed "abhorrence of the idea of a black or Mexican presence" in the same social settings. ${ }^{52}$ Mexicans lived in East Austin too, as well as a part of town that was considered their "Mexico," between Colorado and West Fifth Street..$^{53}$ Today, even if rampant gentrification is changing East Austin and making it less affordable, it is still known as a poorer part of town in which minorities have historically lived ${ }^{54}$ In the documentary, it is therefore not surprising that the Mexican truck has chosen to settle in East Austin to cater to Mexican immigrants. Lemon confirms that the gentrification Austin has been undergoing in the last few years has driven away working-class Latinos (and Anglos) while middle-class Anglos have developed several neighborhoods, included South Austin. ${ }^{55}$ Thus, as he explains, the traditional Latino taco trucks "go largely unnoticed by middle-class Anglo Austinites." ${ }^{56}$ Indeed, when he asks a Mighty Cone's customer if he knows where to find traditional tacos in Austin, the man is incapable of answering the question. More than testifying of a lack of knowledge, it is also telling of the entrenchment of geographical, social and economic borders in Austin.

The main tool that Lemon uses to comment on these borders between the two communities is his presence on screen and the fact that he navigates from one place to the other. More than switching locations, he expresses his opinion about each taco truck after interviewing the owners, the customers and above all, after tasting the food. Numerous elements indicate that he values the Mexican truck more. He seems to wish to convince the viewers that, in his view, the invisibility of the Mexican taco truck in the city does not make sense, since the tacos taste better. Thus, he adds elements that tend to discredit the Mighty Cone, even if he also shows that as it caters to a rather hip population in a famous part of town, experimenting with the food is a relevant business strategy. The eccentricity of the Mighty Cone's owner cuisine is nevertheless highlighted by the infinite list of ingredients that she uses: she can serve pork, chicken, shrimp, or homemade venison sausage, with fried avocado, jalapeño ranch dressing or horseradish mustard, on top of the occasional specials. In other words, the amount of options gives the impression that she is more a businesswoman than a cook, for some of the food associations seem a little far-fetched and not very appetizing. Nevertheless, her success with the taco truck indicates that she has understood the demands of that special place of the city. Yet, as Lemon tries fries at The Mighty Cone, he makes a negative comment about them: "not bad for frozen fries." Though swift, the statement calls into question the freshness of the food and thus unsettles the credibility of the food truck.

On the contrary, the owner of El Guero in East Austin is presented as a cook who has acquired experience from his father and who keeps traditions alive. The sequence 
showing him preparing tacos shows quick efficient gestures as he handles the truck on his own. As he cooks food Federal District style, he only has a few ingredients. Though just like the owner of The Mighty Cone, his business strategy matches the demands of his customers, his approach is constantly showed to uphold tradition. His customers are mostly Mexican families seeking to share these traditions with their children. So, just like Sosa, Lemon plays on the emotional potential of the stories told by the Latinos and on the nobility of tradition. As Ernesto Hernandez-Lopez explains, food consumption "is a negotiation of macro-borders, such as the political boundaries crossed to migrate internationally from Mexico to the U.S., and individual remembrance of the journey and what remains abroad." ${ }^{57}$ The testimonies illustrate this assertion and show people who are deeply affected by their living abroad and who use food as a symbolic travel medium not to forget their roots. The emotional quality serves a rhetorical function as it highlights the hardships undergone by immigrants while coming to the United States.

While it makes sense from the standpoint of identity for Anglos to eat in South Congress and Mexicans to order from El Guero in East Austin, Lemon erases the boundaries between the two in and with his movie. The last scene follows him as he walks to the truck, orders in Spanish and tastes the Mexican taco. His first words are "nice and simple." Thus, the food contrasts with the fancy experimental taco sold at The Mighty Cone (Figure 7) since there's "a little cheese only." As the image fades out and the ending credits starts rolling, Lemon's voice resonates with his satisfaction. Choosing this sequence for the last scene of the movie betrays his intention to convince the (Anglo) viewers to try the Mexican tacos and thus, to go beyond their comfort zones in Austin. His crossing of boundaries seems to be the most eloquent lesson of the documentary. In the movie, Lemon goes beyond the city's taken for granted borders as he moves from South Congress to the taco truck in East Austin and even to the Mexican market. He might have a Mexican grandfather, but he strongly identifies as American. ${ }^{58}$ Thus, there are reasons to believe that his behavior is supposed to be a model for Anglo consumers so that they discover the traditional recipe of the food they love.

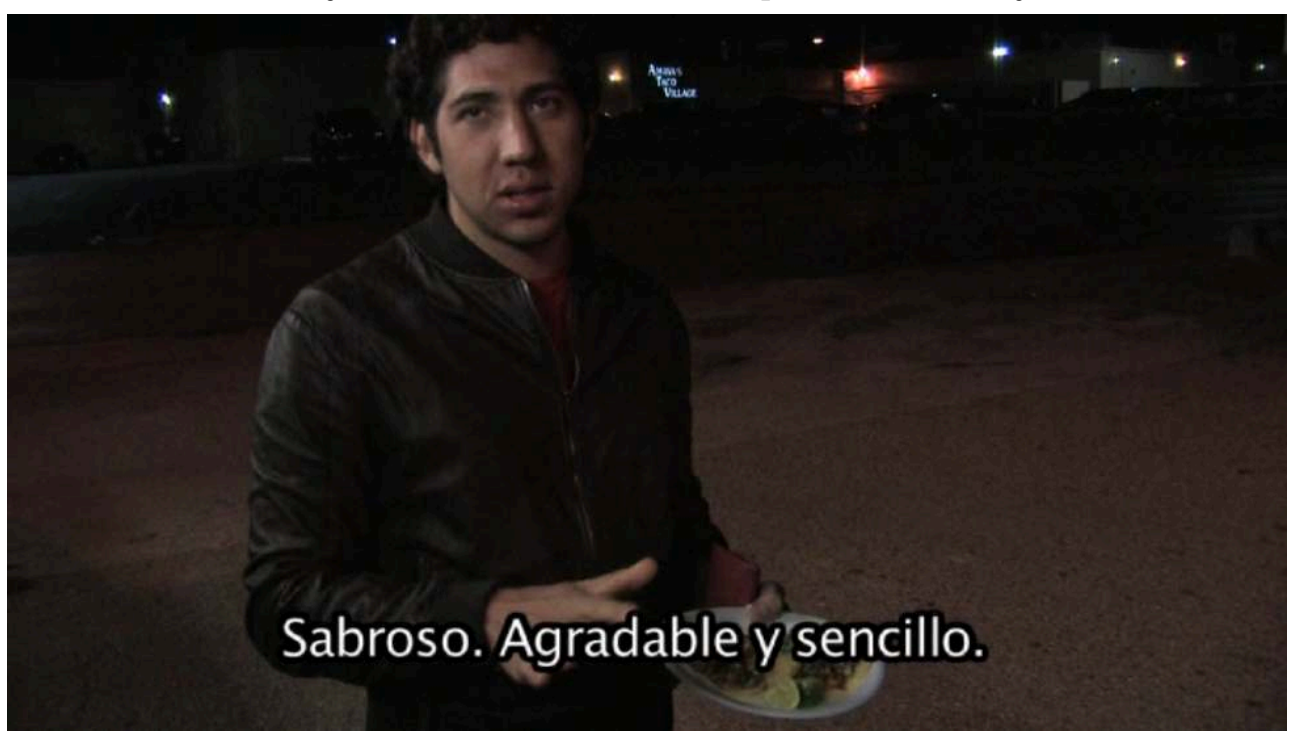

Figure 7. Lemon compares the food at The Mighty Cone and at El Guero

In addition, his special enjoyment of the traditional taco and his disinterest for The Might Cone's food goes beyond the matter of taste. The disappearance of the traditional 
flavors of Mexican cuisine in the preparation of "bourgeois" tacos, more than representing a classic case of mainstream co-optation, seems to mirror the gentrification of the city and the push of Mexican immigrants further away from the most visible parts of town. Now, when Lemon insists on the fact that taco trucks "are" Mexican culture, he replaces the latter at the center of the picture and reminds the viewers that American culture has borrowed the use of food trucks because of its historical entanglement with Mexico and Mexican immigrants. This reference goes back to a time when Texas was still a Mexican province progressively colonized and later annexed by the United States after the Mexican-American War of $1848 .{ }^{59}$ The film shows that Mexican culture has contributed to an important part of American culture and is also a reminder that hybridization is at the core of American culture. After all, as Janer Zilkia eloquently argues, "if you think of iconic and quintessentially American foods, those with which we are most familiar, there are scarcely any truly native to North America." ${ }^{60}$ Therefore, when Lemon's documentary points to the hybrid quality of American food, he implies that without the process of hybridization, Tex-Mex would not exist and by extension, neither would "SoCoMex."

Dear and Burridge explains that the negative aspects of hybridization might be dislocation and loss of traditions, which justifies the immigrants' behaviors and their need to protect their traditions. But he also points to the positive aspects, supposed to bring forth "a broadening of cultural offerings and a challenge to entrenched attitudes on race." ${ }^{61}$ Even if the documentary shows the diversity of cultural offerings in Austin, it is obvious that the challenge they refer to has not been accepted yet, except for Lemon himself. In the title of the movie itself, he does not establish a hierarchy between the two kinds of tacos: they are both different versions of tacos that are relevant, even if he seems to prefer the traditional recipe. Tacos (and taco trucks) are Mexican culture but are also American culture, which suggests that both options can (and should) be consumed interchangeably. The movie seems to be saying that the rich culinary landscape of Austin has a great deal to gain in getting rid of its social, cultural but above all cognitive restrictive borders.

\section{Conclusion}

These two documentaries have showed that the issue of consumerism goes beyond the mere choice of a certain product. It is rooted in social and cultural processes that influence particular groups to consume in a particular way. As such, it was confirmed that Latino immigrants have a special way of consuming that is directly linked to the perception of their social position in American society. The analysis has also shown that the history of intergroup relations can reinforce the idea that one community belongs to a particular neighborhood. This "felt" identity in turn colors the behaviors and urges immigrants to either mimic American ways in search of cultural belonging or keep their ways to preserve their inherited cultural identity.

41 These two shorts-as they belong to a genre of movies whose purpose is to convincealso comment on the perceived excessive visibility Latinos can be accused of, and point to a lack of integration due to biases and fears that have long been an issue in the history of the United States. The portrayal of Latinos is thus that of individuals who contribute to the economic and cultural components of the American society, either as hard-workers or as inspiration for food creativity and hybridization. Not only do they 
highlight the positive and necessary aspects of the presence of Latinos in the U.S., but they offer a portrayal that sheds light on qualities that are in tune with American values, such as work and family. The two films point to the paradoxes of not acknowledging people who work hard and whose culture has contributed to American culture.

What these two movies comment on in fact is the existence of social, cultural and geographical boundaries, but especially ingrained cognitive boundaries that shape people's behavior. Robert Lemon, when crossing these boundaries while traveling across Austin and eating from the two venues, adopts an anti-stereotypical behavior that reminds of the strategies used by Cine Las Americas itself. Indeed, the festival is organized in two venues: a mainstream movie theater, usually the Alamo Drafhouse Lamar, and the Mexican American Cultural Center (MACC) in East Austin in which documentaries are showed for free. More than being a choice supposed to give access to Mexican immigrants to the festival, it is also an encouragement to cross the borders of the city and as such, to change one's stereotypical behavior. Thus, such documentaries and festivals offer strategies of cultural diplomacy that will remain all the more necessary and relevant in the following decades as Latinos become the "majority minority" with $30 \%$ of the population and as further hybridization (and latinization) occurs at al levels of American society. ${ }^{62}$

\section{BIBLIOGRAPHY}

Anderson, Benedict. Imagined Communities: Reflections on the Origin and Spread of Nationalism. London: Verso, 1991.

Appadurai, Arjun. Modernity at Large: Cultural Dimensions of Globalization. University of Minnesota Press. 1996.

Barthes, Roland. "Towards a Psychosociology of Contemporary Food Consumption." In Food and Culture: A Reader, edited by Carole Counihan and Penny Van Esterik. (New York: Routledge, 2008).

Bernardi, Daniel, ed. The Persistence of Whiteness: Race and Contemporary Hollywood Cinema. New York: Routledge, 2008.

Bourdieu, Pierre. La distinction: critique sociale du jugement. Paris: Ed. de Minuit, 1992.

Brammer, John Paul. "Taco trucks on every corner? That'd really make America great again.” The Guardian, September 2, 2016. Accessed October 31, 2018. https://www.theguardian.com/ commentisfree/2016/sep/02/taco-truck-on-every-corner-trump-mexican-marco-gutierrez Bureau of Labor Statistics, "Hispanics and Latinos in industries and occupations," October 9, 2015, accessed May 13, 2018, https://www.bls.gov/opub/ted/2015/hispanics-and-latinos-inindustries-and-occupations.htm.

Chávez, Christopher. Reinventing the Latino Television Viewer: Language, Ideology, and Practice. Lanham: Lexington Books, 2015. 
Chavez, Leo R. "Outside the Imagined Community: Undocumented Settlers and Experiences of Incorporation.” American Ethnologist, Vol. 18, No. 2 (May, 1991): 257-278.

Chavez, Leo R. The Latino threat: construction immigrants, citizens, and the nation. Stanford, California: Stanford University Press, 2013.

Cine Las Americas. “About us, Our history.” Accessed July 16, 2015. http:// www.cinelasamericas.org/.

Cine Las Americas. "Home." Accessed August 22, 2017. http://www.cinelasamericas.org/.

Cohen, James. Spanglish America : les enjeux de la latinisation des Etats-Unis. Paris: le Félin, 2005.

Dávila, Arlene M., Latinos, Inc.: The Marketing and Making of a People. Los Angeles, Calif: University of California Press, 2001.

Dear, Michael, and Andrew Burridge. "Cultural Integration and Hybridization at the United States-Mexico Borderlands.” Cahiers de Géographie Du Québec 49, 138 (2005): 301-318.

De León, Arnoldo. Mexican Americans in Texas: a brief history. Wheeling, Ill: Harlan Davidson, 2009. Halter, Marilyn. Shopping for Identity: The Marketing of Ethnicity. New York: Schocken books, 2000. Hebdige, Dick and Andrew Potter, "A Critical Reframing of Subcultural Cool and Consumption," European Advances in Consumer Research, Vol. 8, eds Stephania Borghini, Mary Ann McGrath, and Cele Otnes (Duluth, MN : Association for Consumer Research) : 527-530.

Hernàndez-López, Ernesto. “LA's Taco Truck War: How Law Cooks Food Culture Contests.” The University of Miami Inter-American Law Review, 43 no.1 (2011): 233-268.

Hesford, Wendy S. "Documenting Violations: Rhetorical Witnessing and the Spectacle of Distant Suffering.” Biography 27, 1 (2004): 104-144.

Humphrey, David C. Austin: An Illustrated History. Sun Valley, California: American Historical Press, 2001.

Hura, Alexa. “Texas Hispanics behind half of state's growth since 2010.” The Texas Tribune, June 22, 2017. Accessed August 10, 2017. https://www.texastribune.org/2017/06/22/texas-hispanicsbehind-half-states-growth-2010/.

Jimenez, Tomas. The Other Side of Assimilation: How Immigrants Are Changing American Life (Berkeley : University of California Press, 2017).

Lemon, Robert D. “The Budding Aromas from Taco Trucks: Taste and Space in Austin, Texas." Transnational Marketing Journal, 4 no. 2 (2016): 100-109.

Lesser, Gabriel, and Jeanne Batalova. "Central American Immigrants in the United States." Migration Policy Institute, April 5, 2017. Accessed August 10, 2017. https:// www.migrationpolicy.org/article/central-american-immigrants-united-states.

Lindenfeld, Laura. "Visiting the Mexican American Family: Tortilla Soup as Culinary Tourism." Communication and Critical/Cultural Studies, Vol 4., 3 (September 2007): 303-320.

Lippert-Rasmussen, Kasper. "Immigrants, Multiculturalism, and Expensive Cultural Tastes: Quong on Luck Egalitarianism and Cultural Minority Rights," Les ateliers de l'éthique 6 (automne 2011) :176-192, accessed April 29, 2018, doi :10.7202/1008037ar.

Long, Joshua. Weird City: Sense of Place and Creative Resistance in Austin, Texas. Austin: University of Texas Press, 2010. 
McDonald, Jason. Racial dynamics in early twentieth-century Austin, Texas. Lanham, Md: Lexington Books, 2012.

Nichols, Bill. Introduction to Documentary. Bloomington, Ind. :Indiana university press, 2001.

Passel Jeffrey S. and D’Vera Cohn, “U.S. Population Projections: 2005-2050," Pew Research Center, February $11 ; 2008$, accessed November 1, 2018, http://www.pewhispanic.org/2008/02/11/uspopulation-projections-2005-2050/.

Ramírez Berg, Charles. Latino Images in Film. Stereotypes, Subversion, Resistance. Austin: University of Texas Press, 2002.

Sosa, Irene. "Shopping to Belong." Accessed September 15, 2016. http://www.irenesosa.com/ irenesosa.com/Shopping_to.html.

Stayman, Douglas M. and Rohit Deshpande. "Ethnicity and Consumer Behavior." Journal of Consumer Research 16, No. 3 (December 1989): 361-371.

Ting-Toomey, Stella. "Identity negotiation theory," IN J. Bennett (Ed.), Sage Encyclopedia of Intercultural Competence, Vol. 1 (Los Angeles, CA: Sage) : 418-422.

United States Census Bureau. "Hispanics in the United States." Accessed May 8, 2017. https:// www.census.gov/population/www/socdemo/files/Internet_Hispanic_in_US_2006.pdf.

United States Census Bureau. “Quick facts - Austin, Texas.” Accessed May 8, 2017. https:// www.census.gov/quickfacts/fact/table/austincitytexas,austincityminnesota,TX/PST045216.

Wight, Craig. "Reengineering Authenticity. Tourism Encounters with Cuisine in Rural Great Britain," in Food for Thought : Essays on Eating and Culture, ed. Lawrence C. Rubin (Jefferson, N.C.: McFarland, 2008), 154.

YouTube. Lemon, Robert. “¿Tacos o Tacos?.” December 8, 2010. Accessed September 18, 2016. https://www.youtube.com/watch?v=3Gy2LbRdoMc.

Zilkia, Janer. Latino Food Culture (Westport, CT: Greenwood Press, 2008).

Zmud, Johanna and Carlos Arce. "The Ethnicity and Consumption Relationship." Advances in Consumer Research 19: 443-449.

Zukin, Sharon. "Gentrification: Culture and Capital in the Urban Core." Annual Review of Sociology, Vol. 13 (1987): 129-147.

\section{ENDNOTES}

1. "Hispanics in the United States," United States Census Bureau, accessed on May 8, 2017, https://www.census.gov/population/www/socdemo/files/Internet_Hispanic_in_US_2006.pdf.

2. Laura Lindenfeld, "Visiting the Mexican American Family: Tortilla Soup as Culinary Tourism," Communication and Critical/Cultural Studies, Vol. 4, 3 (September 2007), 306.

3. See Christopher Chavez, Reinventing the Latino Television Viewer: Language, Ideology and Practice (Lanham : Lexington Books, 2015) for an analysis of the marketing strategies created by different TV networks and Arlene M. Dávila, Latinos, Inc. : The Marketing and Making of a People (Los Angeles, California : University of California Press, 2001) for an in-depth analysis of the marketing power of Latinos.

4. James Cohen, Spanglish America. Les enjeux de la latinisation des États-Unis (Paris: Le Félin, 2005), 9. 
5. Gabriel Lesser and Jeanne Batalova, "Central American Immigrants in the United States," Migration Policy Institute, April 5, 2017, accessed August 10, 2017, https:// www.migrationpolicy.org/article/central-american-immigrants-united-states.

6. See for instance Chavez, Reinventing the Latino Television Viewer.

7. In Latinos, Inc., Dávila discusses the fact that it is often easier to consider they are interchangeable. Yet, "Hispanic" tends to be used by governmental agencies whereas, as Janer Zilkia explains, "Latino" is a term of "self-affirmation".

8. Davila, Latinos, Inc.

9. Leo R. Chavez, The Latino Threat: constructing immigrants, citizens, and the nation (Stanford: California: Stanford University Press, 2013).

10. These categories are listed in charts in the anthology edited by Dina Iordanova. As of 2018, a series of six books have been published to explore different aspects of films festivals. http:// stafs.org/series/film-festival-yearbooks/

11. “About us, Our history," Cine Las Americas, last accessed July 16, 2015, http:// www.cinelasamericas.org/. The festival's website was simplified at the end of 2015 for the $18^{\text {th }}$ festival after the new director, Jean Anne Lauer, took over. The information about the history of the festival has been removed.

12. Charles Ramírez Berg, Latino Images in Film: Stereotypes, Subversion, Resistance (Austin: University of Texas Press, 2002), 118.

13. Dávila, Latinos, Inc., 2.

14. "Home," Cine Las Americas, accessed August 22, 2017, www.cinelasamericas.org/.

15. The "artistic excellence" of the films selected is advocated in the introduction of the program of the 14th festival written by the former festival director, Eugenio Del Bosque.

16. Alexa Hura, "Texas Hispanics behind half of state's growth since 2010," The Texas Tribune, June 22, 2017, accessed August 10, 2017, https://www.texastribune.org/2017/06/22/texashispanics-behind-half-states-growth-2010/.

17. "Quick facts - Austin, Texas," United States Census Bureau," accessed May 8, 2017, https:// www.census.gov/quickfacts/fact/table/austincitytexas,austincityminnesota,TX/PST045216.

18. Irese Sosa, Skype interview with author, December 10, 2017.

19. Robert Lemon, written interview with author, April 4, 2016.

20. Dávila, Latinos, Inc., 2.

21. Lindenfeld, "Visiting the Mexican American Family," 303.

22. Anglo is a term to refer to white people mostly of European descent.

23. The research about assimilation has been one of the most flourishing in the U.S. Starting with Milton Gordon stating that it was a linear process with seven stages, it has since tremendously evolved to take into account societal changes but also broaden the research according to the new waves of immigrants. See Emily Greenman and Yu Xie, «Is Assimilation Theory Dead? The Effects of Assimilation on Adolescent Well-being, » Social Science Research, Vol. 37, 1 (2008): 109-137.

24. Marilyn Halter, Shopping for Identity: the marketing of ethnicity (New York: Schocken Books, 2000), 7.

25. Benedict Anderson, Imagined Communities: Reflections on the Origin and Spread of Nationalism (London: Verso, 1991).

26. Arjun Appadurai, Modernity at Large: Cultural Dimensions of Globalization (University of Minnesota Press, 1996).

27. Leo R. Chavez, "Outside the Imagined Community: Undocumented Settlers and Experiences of Incorporation," American Ethnologist, Vol. 18, No. 2 (May, 1991), 259.

28. Tomas Jimenez, The Other Side of Assimilation: How Immigrants Are Changing American Life (Berkeley : University of California Press, 2017), xi-xiv. 
29. Kasper Lippert-Rasmussen, "Immigrants, Multiculturalism, and Expensive Cultural Tastes: Quong on Luck Egalitarianism and Cultural Minority Rights," Les ateliers de l'éthique 6 (automne 2011): 176-192, accessed April 29, 2018, doi :10.7202/1008037ar.

30. Stella Ting-Toomey, "Identity negotiation theory," IN J. Bennett (Ed.), Sage Encyclopedia of Intercultural Competence, Vol. 1 (Los Angeles, CA: Sage) : 418-422.

31. Douglas M. Stayman and Rohit Deshpande, "Situational Ethnicity and Consumer Behavior," Journal of Consumer Research, 163 (Dec., 1989): 361-371.

32. Johanna Zmud and Carlos Arce, "The Ethnicity and Consumption Relationship ," Advances in Consumer Research 19, 1 (1992) : 443-449.

33. Dear, Michael, and Andrew Burridge "Cultural Integration and Hybridization at the United States-Mexico Borderlands” Cahiers de Géographie Du Québec 49, 138 (2005): 301-318.

34. Dear and Burridge "Cultural Integration and Hybridization at the United States-Mexico Borderlands," 303.

35. Pierre Bourdieu, La distinction: critique sociale du jugement (Paris: Ed. de Minuit, 1992).

36. Wendy S. Hesford, "Documenting Violations: Rhetorical Witnessing and the Spectacle of Distant Suffering," Biography 27, 1 (2004): 105.

37. "acostumbrarse a la vida de este país, lo que es trabajo, la diversion, shopping." (translated by the author)

38. "Me fascina Marshalls porque Marshalls te consigue la mercancía de Buena calidad a un bajo precio." (translated by the author)

39. Roland Barthes, "Towards a Psychosociology of Contemporary Food Consumption," IN Food and Culture: A Reader, edited by Carole Counihan and Penny Van Esterik. (New York: Routledge, 2008), 29.

40. Craig Wight, "Reengineering Authenticity. Tourism Encounters with Cuisine in Rural Great Britain." In Food for Thought: Essays on Eating and Culture, ed. Lawrence C. Rubin (Jefferson, N.C.: McFarland, 2008), 154.

41. Roland Barthes, "Towards a Psychosociology of Contemporary Food Consumption," In Carole Counihan and Penny Van Esterik, Eds. Food and Culture (New York: Routledge, 2008), 27.

42. Dick Hebdige and Andrew Potter, "A Critical Reframing of Subcultural Cool and Consumption," European Advances in Consumer Research, Vol. 8, eds Stephania Borghini, Mary Ann McGrath, and Cele Otnes (Duluth, MN: Association for Consumer Research): 527-530.

43. John Paul Brammer, "Taco trucks on every corner? That'd really make America great again." The Guardian, September 2, 2016, accessed October 31, 2018. https://www.theguardian.com/ commentisfree/2016/sep/02/taco-truck-on-every-corner-trump-mexican-marco-gutierrez

44. Irese Sosa, Skype interview with author, December 10, 2017.

45. Daniel Bernardi, ed, The Persistence of Whiteness : Race and Contemporary Hollywood Cinema (New York : Routledge, 2008).

46. Dávila, Latinos Inc., 11.

47. "Hispanics and Latinos in industries and occupations," Bureau of Labor Statistics, October 9, 2015, accessed May 13, 2018, https://www.bls.gov/opub/ted/2015/hispanics-and-latinos-inindustries-and-occupations.htm.

48. Dávila, Latinos Inc., 11.

49. Dávila, Latinos Inc., 83.

50. Lindenfeld, "Visiting the Mexican American Family," 305.

51. David C. Humphrey, Austin: An Illustrated History (Sunvalley: Cali, American Historical Press, 1937), 185.

52. Jason McDonald, Racial dynamics in early twentieth-century Austin, Texas (Lanham, Md: Lexington Books, 2012), 80.

53. Humphrey, Austin: A, Illustrated History, 178. 
54. Joshua Long, Weird City: Sense of Place and Creative Resistance in Austin, Texas (Austin: University of Texas Press, 2010), 55-57.

55. Long, Weird City, 71-74.

56. Robert Lemon, "The Budding Aromas from Taco Trucks," Transnational Marketing Journal, 4 , no. 2 (2016): 102.

57. Ernesto Hernàndez-López, "LA's Taco Truck War: How Law Cooks Food Culture Contests," The University of Miami Inter-American Law Review, 1 (2011): 263.

58. Robert Lemon, written interview with author, April 4, 2016.

59. Arnoldo De León, Mexican Americans in Texas: a brief history (Wheeling, Ill. : Harlan Davidson, 2009), 31.

60. Janer Zilkia, Latino Food Culture (Westport, CT: Greenwood Press, 2008), ix.

61. Dear and Burridge, "Cultural Integration and Hybridization at the United States-Mexico Borderlands," 303.

62. Jeffrey S. Passel and D'Vera Cohn, “U.S. Population Projections: 2005-2050," Pew Research Center, February 11, 2008, accessed November 1, 2018, http://www.pewhispanic.org/2008/02/11/ us-population-projections-2005-2050/.

\section{ABSTRACTS}

This article analyzes two short documentaries showed at Cine Las Americas International Film Festival (Austin, Texas) and the way they discuss the symbolic meaning as well as the implications of consumption for U.S. Latinos at the personal, social, cultural, and economic levels. Shopping to Belong (Irene Sosa, 2007) insists on the performance Latinos put on in order to blend in American society and strengthen their sense of belonging, and ¿Tacos o Tacos? (Robert Lemon, 2011) compares the different consumption patterns showed by Mexican immigrants and Anglos in Austin while also commenting on the hybridization of food in the Texan capital. Using immigrants as the main interviewees, both documentaries further discussions about the negotiable quality of identity, their efforts to assimilate in spite of the obstacles they might encounter, and generally speaking intergroup relations in the United States. The study takes into account the fact that the films were shown at a Latino film festival and thus, seek to offer a counter-stereotypical view of Latino immigrants and participate in the debate about their cultural visibility.

\section{INDEX}

Keywords: U.S. Latinos, taco trucks, immigration, assimilation theory, film festival, documentary film

\section{AUTHOR}

\section{EMILIE CHEYROUX}

Emilie Cheyroux holds a PhD in American Studies from the University Paris 3 Sorbonne Nouvelle. Her dissertation dealt with a Latino film festival's strategies to deconstruct stereotypes about Latinos in the United States, and more particularly in the city of Austin, Texas. Her research took into account the analysis of the festival's program as well as its local impact and networking strategies. 